\title{
ГУМАНИЗМ «ПЛАНЕТАРНОЙ» ФИЛОСОФИИ В.И. ВЕРНАДСКОГО В КОНТЕКСТЕ СОВРЕМЕННЫХ ГЛОБАЛЬНЫХ ТРАНСФОРМАЦИЙ
}

\section{Л.А. Медведева, Р.И. Амирова}

Переориентация интересов познания мира, которая, на наш взгляд, происходит в последние годы в науке, существенно повлияла и на проблематику философских исследований, где на первый план выходит изучение тем, которые, с точки зрения предшествующей официальнодогматической философии, были периферийными.

Прежде всего, следует сказать о проблемах человека и гуманизма, которые сегодня оказались в фокусе философских размышлений о перспективах развития цивилизации, поиска критериев и концепций решения проблем коэволюции человека и биосферы.

То, что будущее биосферы, в связи с деятельностью человека, стало предметом пристального внимания представителей многих отраслей научного знания, уже само по себе может быть достаточным основанием для выделения особой группы вопросов - философско-методологических проблем прогнозирования будущего, решение которых является одним из важнейших требований развития человеческой культуры на современном этапе ее глобальных трансформаций.

Глобальные проблемы - проблемы антропогенного воздействия на природу, возникновения явного противоречия между уровнем мирового социально-экономического развития с ресурсовоспроизводящими и жизнеобеспечивающими возможностями биосферы - превратились сегодня в предмет особого внимания мирового сообщества и обусловили повышенный рост научных исследований и всеобщий интерес к 
глобалистике.

Справедливость однако требует отдать приоритет в постановке и глубоком исследовании ряда естественно-научных, философских и мировоззренческих вопросов выдающемуся естествоиспытателю и мыслителю В.И.Вернадскому, научное наследие которого имеет чрезвычайную эвристическую ценность для осмысления современных глобальных трансформаций. В истории науки немного найдется людей, которые могли бы быть поставлены в один с ним ряд по степени влияния на ход научной работы, по глубине и оригинальности их обобщающей мысли. Многие идеи В.И. Вернадского настолько глубоко вошли в плоть и кровь научных исканий и философских размышлений о путях развития человечества, что стали жить как бы сами по себе, превратились в обезличенные эвристические истины, до сих пор поражающие своей гениальностью и прозорливостью. В современной литературе, проблематика которой так или иначе связана с вопросами возникновения и развития человечества, его будущего, наиболее выражены концепции, развивающие представления и идеи «планетарной» философии В.И. Вернадского, в центре которой находится его учение о ноокосмогенезе.

Как заметил В.И. Вернадский в одной из бесед с С.Ф. Ольденбургом, мировой характер социально-политических процессов явно исходит из более глубокого субстрата человеческой истории - из геологического субстрата, из нового состояния биосферы, переходящей в ноосферу, внутри которой человечество впервые становится мощной планетной геологической силой и где геологически должны проявиться его мысль, его сознание, его разум.

Под ноосферой, в соответствии с идеями В.И. Вернадского, понимается «тот этап естественного развития нашей планеты (системы Геи), который сменяет эпоху спонтанного, стихийного, неконтролируемого разумом развития производительных сил, этап, на котором общество должно соизмерить свои потребности с возможностями биосферы... когда человеческий интеллект должен взять на себя заботу и ответственность за судьбу планеты. Ее дальнейшее развитие должно теперь сделаться направляемым, ориентированным на общие цели» ${ }^{1}$.

Обобщения В.И. Вернадского, касающиеся теории эволюции, логически неизбежно указывают на существование определенного направления, в котором должен идти эволюционный процесс неизменного геологического времени.

${ }^{1}$ Моисеев Н.Н. Алгоритмы эволюции.-М., 1987.-С. 216. 
Взятая в целом, палеонтологическая летопись имеет характер не хаотического изменения, идущего то в ту, то в другую стороны, а явления определенного, развертывающегося в направлении усиления сознания и мысли, создания форм, все более углубляющих влияние жизни на окружающую среду. Иными словами, ноосфера как человеческое творение - это не просто некая дисгармоническая реальность, в силу несовершенства самого человека пребывающая в процессе своего становления, но и определенный идеал (цель) этого становления, потребность в котором собственно и создает ноосферную оболочку планеты. Это естественный и закономерный процесс, который неразрывно связан с внутренне присущей человеку креативной потребностью превзойти себя в своем сегодняшнем социальном и биологическом качестве, ибо человек есть часть культурной биохимической энергии, связанной с развитием мозга, появлением разума и развитием духовности личности.

Разумеется, следует учитывать, что научные основания концепции ноокосмогенеза формировались в первой половине прошлого века и, естественно, многие конкретно-научные представления В.И. Вернадского должны в настоящее время уточняться. Но устарели ли ее философские посылки? Конечно ли человечество, как считают члены Римского клуба, либо можно смотреть в будущее с безудержным оптимизмом, переступив через мефистофелевское «все, что возникает, заслуживает гибели»? Не вдаваясь в детали и подробности разнообразных и порой досужих рассуждений алармоэсхатологического и радужновикторианского толка, отметим только их непродуктивность, нежизненность и бесперспективность. Гораздо ближе для нас по мировоззренческим установкам, мироощущению и мировосприятию-исторический оптимизм материалистической концепции будущего В.И. Вернадского, хотя мы склонны давать происходящим ныне глобальным процессам несколько иную интерпретацию.

«Я чрезвычайно оптимистично смотрю на жизнь ближайших поколений и думаю, - говорил В.И. Вернадский, - что уже сейчас рождается ноосфера, а значит страхи «о возможном крушении цивилизации ... лишены основания», ибо «никогда не было в истории человечества, ныне наблюдаемой его вселенскости, с одной стороны, и с другой стороны, отсутствия оторванности отдельных поселений благодаря быстроте сношений и передвижений... $»^{2}$.

${ }^{2}$ Вернадский В.И. Размышления натуралиста: Научная мысль как планетарное явление. - М., 1977.-С. 36. 
Мы живем, писал В.И.Вернадский в «Размышлениях натуралиста», на переломе эпох в жизни человечества и ныне живущие поколения планеты переживают «коренную ломку научного мировоззрения», которая до неузнаваемости расширяет научно охватываемый космоси в его пространстве и в его времени, радикально перестраивают свои представления о месте и потенциальньх возможностях человечества.

Следует, однако, заметить, что несмотря на подчас наивно-реалистический и восторженно-романтический характер «планетарной» натурфилософии В.И. Вернадского, его нелинейное, эвристическое мышление охватывало не только актуальную субстанцию явлений, но и позволяло делать весьма точные прогностические умозаключения. Именно подобный подход позволил ему, говоря о превращении человечества в мощную геополитическую силу, преобразующую биосферу, предвидеть возможность возникновения ситуаций, которые несколько десятилетий спустя получат название «глобальные проблемы современности». Поэтому неудивительно, что в условиях современных социальнополитических, экономических и культурньх трансформаций, в условиях обострения связанных с ними глобальных проблем, многие исследователи обращаются к научному наследию основоположника материалистической концепции ноокосмогенеза, пытаясь найти у него ответы на волнующие их вопросы о месте человека в природе и биосфере, о будущем их коэволюции, о судьбах мировой цивилизации в целом.

Различая эти проблемы по характерным макропредикатам, можно свести их к трем основным группам социально-аксиологических задач, требующих своего решения на пути в будущее человеческой цивилизации: отношение человека с самим собой (человеческая перспектива), отношения человека с окружающим миром (глобальная перспектива) и отношения человека с окружающей средой и ее ресурсами (управленческая перспектива). Каждая из этих задач требует глубокого и всестороннего изучения в рамках отдельных синергетических исследований, охватывающих не только конкретно-научные эмпирические основания явления, но и его морально-этические, гуманистические аспекты, итогом которых (исследований) может стать формирование соответствующей парадигмы удовлетворения потребностей функционирования отдельного геосоциума и в целом мирового сообщества в экологической, научно-культурной и морально-нравственной сферах.

Вместе с тем следует подчеркнуть, что несмотря на определенные отличия, в центре любой из выделенных нами групп находится человек - источник и средоточие всех возможных синергетических векторов эволюционного развития как внутри каждой из них, так и в их 
совокупном единстве. Причем не просто человеческий индивид, а человек, который впервые реально ощутил себя жителем планеты, может и должен думать и действовать в этом новом амплуа не только как личность, принадлежащая к отдельной семье, роду, государству или их союзам, но и в планетарном масштабе, что многократно умножает значение той истины, что основной проблемой философии есть проблема человека. Как замечал еще Н.Бердяев, разгадка бытия для человека скрыта в самом человеке. «Человек, - писал он, - не есть дробная часть мира, в нем заключена цельная загадка и разгадка мира» ${ }^{3}$.

Bсе это указывает на то, что эпохи, двигателями которых были только «сильные мира сего», остались позади, и миллионы людей уже не смогут «умыть руки» подобно Понтию Пилату.

Мир вступает в новую полосу своей эволюции, где соотношение исторической необходимости и свободы будет иным, чем во всей предшествующей истории, что связано с процессами трансформации постиндустриального общества в современный глобализирующийся информационно-технический социум, объединиться в который человечеству не дано, не достигнув хоть какого-то гуманистического согласия, представляющего собой высшее культурное и нравственное развитие человеческих способностей в сочетании с мягкостью, терпимостью, ненасилием и человечностью; то есть фактически основополагающие структурные компоненты ноосферы В.И. Вернадского.

Современная история человечества, вследствие громадных изменений в предметной среде, в которой непосредственно протекает человеческая жизнедеятельность (возникновение новых форм кооперирования человеческого труда, новых форм коммуникаций, передачи и хранения информации, новых форм взаимодействия локальных культур и т. п.), на наших глазах становится глобальной историей, а человечество во всех его ипостасях и во всех его основных измерениях становится интегральным целым, подтверждая тем самым гениальность одной из самых существенных мыслей предшествующей философии, уходящей корнями едва ли не в первозданные пласты разных культур. Об этом говорили и древние греки, и восточные мудрецы, и средневековые мыслители, делая акцент на том, что мы должны рассматривать человечество как великое собирательное существо, как социальный организм, структурные элементы которого (нации, народы, государства) не могут жить в себе и только для себя, но жизнь каждого народа представляет лишь определенное участие в общей жизни человечества.

${ }^{3}$ Бердяев Н.А. Смысл истории.-- М., 1990.-С. 258. 
Современные ускоренные, как бы спрессованные во времени, темпы цивилизационого развития многое меняют в социальной и культурной жизни мирового социума. Ряд базисных ценностей индустриального общества проблематизируется, возникают точки роста новых ценностных установок и ориентаций, открываются новые перспективы диалога культур. Их изучение предполагает выяснение новых смыслов мировоззренческих универсалий, формирующихся в науке, технологиях, искусстве, нравственности, политическом и правовом сознании. Причем не в плане построения абстрактных умозрительных конструкций, а как практическая потребность определять и прогнозировать возможные стратегии развития цивилизации. Хотя уже сегодня вполне очевидно, что главным продуктом глобализирующейся техногенной цивилизации есть коммуникативная общественная система, парадигма становления и эволюции которой лежит не в плоскости технологии, а в среде социогуманитарных форм развития, которые существенно трансформируют общественные отношения на принципах социального партнерства, социально-этнического равенства, геосоциальной справедливости и гуманизма. Мир стоит на пороге эпохи «глобального диалога» и «глобальной этики», о чем все увереннее говорит большинство исследователей, занимающихся его комплексным изучением, однако эта потребность человечества во всеобщем планетарном единении может быть реализована только на основе новой ценностно-гуманистической культурной парадигмы, основное смыслообразующее содержание которой заключается в том, что состояние диалога равных партнеров есть мера гуманизма культуры человека и социума, а монологизм синоним антигуманности, ибо жить, как заметил М. Бахтин, «значит принимать участие в диалоге ... всей жизнью: глазами, губами, руками, душою, духом, поступками» ${ }^{4}$. Истина, по Бахтину, и мы вполне разделяем его точку зрения, рождается не в голове отдельного человека, она рождается среди людей, которые ищут и находят ее в процессе диалогического общения, в процессе совместного духовного творчества.

В этом смысле образно, но весьма точно, высказал эту же мысль В. Леви: «Решить личные, междуличные или групповые проблемы, решить проблемы, какие бы то ни было, внутри своей скорлупы, автономии любой степени и названия, невозможно, не вьходя на Связь, запираясь. Закрываясь от сквозняка жизни - задохнешься, протухне-

\footnotetext{
${ }^{4}$ Бахтин М. Эстетика словесного творчества. - М., 1986.-С. 318.
} 
шь. А чтобы выйти, нужна работа. Пробить свою скорлупу» ${ }^{5}$. «Выйти на Связь», почувствовать свою уникальность и неповторимость, идентифицируя себя с другим, - это ощущение продолженности себя в другом явно или имплицитно присутствует в экзистенции человека на всех этапах его цивилизационного развития, хотя и в разной степени выражено у человека естественного (многомерного, духовного) и человека отчужденного (одномерного, бездуховного). И все же, несмотря на значительные социальные трансформации последних лет, несомненные процессы слияния многочисленных подсистем и сфер социальной жизни в единый поток глобального прогресса, эйфория по поводу идей «всеобщего братства и вселенского единения» под знаменем нового гуманизма пока преждевременна, так как подобная жесткая концепция нивелирует и затушевывает массу социально-политических, экономических и гуманитарных различий современного мультикультурного мира.

Интенсивное изменение предметного мира в рамках техногенной цивилизации привело к очень активным трансформациям социальных связей и типов общения людей, форм их коммуникации, образа и качества жизни. Техногенная цивилизация оказалась весьма агрессивной и в плане экстраполяции негативной антропогенной динамики, и в плане не всегда нравственно адекватного воздействия на традиционалистские общественные системы. Именно ее агрессивная природа, несмотря на технические и материальные блага, которые она привнесла в повседневную человеческую жизнь, культ силы, власти и господства над всем, что ей противоположно (в духе философии маскулинизма), буквально поглощает, подавляет и подчиняет себе традиционные цивилизации и их культуры, оттесняя их на периферию, трансформируя их уникальность и самостоятельность на основе своей техногенной культурной матрицы, превращая их в исторически архаичные рудименты. Причем если в своих ранних формах техногенная цивилизация лишь ослабляла барьеры между локальными культурами, то сейчас она уже разрушает культурные табу и традиции, жестко отсекает и пресекает всяческий партикуляризм, ориентируясь на доминирующие внутри нее социокультурные парадигмы, не позволяющие эффективно разрешать проблемы, связанные с негативными последствиями глобализации, возникновением и преодолением кризисных явлений в современном миpe.

Мировому сообществу сегодня известны и объекты спасения (при-

${ }^{5}$ Леви В. Искусство быть собой. - М., 1991.- С. 10. 
рода, культура, человек и безопасность планеты), и стратегия спасения (гуманизм, терпимость, ненасилие, демократия), однако принимаемые им меры в подавляющем большинстве паллиативны и объективно способны лишь ограничить болезненные синдромы, но не в состоянии устранить причину и излечить само заболевание. Все это свидетельствует о том, что индустриальная парадигма идейно износилась, обветшала мировозренчески и морально устарела. Современному глобализирующемуся постиндустриальному обществу, трансформирующемуся в глобальную коммуникативную социетальную систему нужна новая парадигма - парадигма современных глобальных трансформаций, смыслообразующими ценостными характеристиками которой должны стать основанный на взаимодополняющемся физическом и духовном опыте человека гуманизм, философия диалога, переориентация науки, эволюция во взглядах на смысл жизни в направлении усиления духовных потенций человека, понимания его жизненных установок и целей.

Очевидно, в современных условиях на начальном этапе становления ноосферы необходимо добиваться такого состояния общества (человека), которое можно охарактеризовать как дифференцированную интеграцию, становление «мира миров», реализующего себя на основе принципа самодостаточности и планетарных коэволюционных процессов. В этом смысле реконструкция и дальнейшая разработка основных направлений ноокосмогенеза представляется чрезвычайно важной задачей философии и конкретных наук, так как по мнению многих ученых в разных странах мира, предложенная В.И. Вернадским концепция ноосферы, намечает единственный выход для человечества. 